\title{
Factor Analysis of Effect on Cardiovascular Disease of Korean Police Officers
}

\author{
Jingu Lee,***, Woojin Jeon ${ }^{*, * *}$, Jaehwan Cho ${ }^{* *}$ \\ Department of Radiology, National Police Hospital*, \\ Department of International Radiological Science, Hallym University of Graduate Studies**

\begin{abstract}
한국 경찰관들의 심혈관 질환에 영향을 미치는 요인 분석
이진구 ${ }^{* * * *}$, 전우진,**, 조재환**

국립경찰병원 영상의학과*, 한림국제대학원대학교 국제방사선학과**
\end{abstract}

\begin{abstract}
The purpose study is to investigate the correlation between cardiovascular symptoms and factors in police officers, to provide basic data for a systematic and effective resource management of radiation workers in the future. This study was conducted on police officers who visited the national police hospital and who underwent 201T1-SPECT for the diagnosis of cardiovascular diseases. In study result, smokers than non-smokers 1.80 times higher cardiovascular disease. Beside, person with hypertension than those who do not have hypertension 1.63 times higher cardiovascular disease. And, the probability of cerebrovascular disease was 1.82 times higher in patients with a low HDL level.
\end{abstract}

Key words: police officers, cardiovascular disease, factors

\section{요 야}

본 연구는 국내 경찰관들을 대상으로 심혈관질환의 요인을 파악함으로써 추후 경찰관들의 체계적이고 효율적인 자 원관리를 위한 기초자료로 이용하고자 한다. 국립경찰병원을 방문한 경찰관을 대상으로 심혈관질환 진단을 위한 방사 선 검사 중 201T1-SPECT를 시행한 경찰관을 대상으로 분석을 실시하였다. 연구 결과 흡연을 하는 사람은 비흡연자 의 1.80 배, 고혈압 있는 사람은 고혈압이 없는 사람의 1.63 배, 고지혈증이 있는 사람은 없는 사람의 1.48 배, 고밀도지 단백콜레스테롤 $(\mathrm{HDL})$ 이 낮은 사람은 정상수치인 사람의 1.82 배로 심혈관질환이 높았다.

중심단어: 경찰관, 심혈관질환, 요인

\section{I. 서 론}

오늘날의 우리사회는 다양한 가치관과 복잡한 사회 구조를 지니고 있고, 최첨단 기술의 발전들로 빠른 변
화를 이어가고 있다. 이런 빠르고 복잡한 세상의 일선 에서 국민의 안전을 도모하고 책임져야 할 경찰의 역 할은 커져가고 있는데, 경찰관들이 충실히 임무를 수 행할 수 있도록 하기 위해서는 경찰관의 신체적, 정신 적 건강을 위협하는 요인을 조사하고 관리하여 할 필 
요가 있다. 경찰관은 여러 경과와 특기부호에 따라 직 무가 결정되지만 대다수의 경찰관들은 교대근무를 기 본적인 근무형태로 하고 있다. 이런 경찰관의 근무형 태는 수면, 휴식, 식사패턴 등 생체리듬을 변화시키고 이런 변화에 대한 적응을 끊임없이 요구하며 이런 변 화에의 적응은 건강에 더 큰 부담으로 작용하게 되고 [1], 급기야는 몇 년 사이에 매스컴을 통해 경찰관의 심 혈관질환 사고 소식을 쉽게 접하는 상황에 이르렀다리.

심혈관질환은 세계적인 관리질환 일 뿐 아니라 통 계청이 발표한 우리나라 사망원인에서 악성신생물과 뇌혈관질환에 이은 3번째 원인이기도 하다 ${ }^{[3]}$. 2011년 현재 한국인의 기대수명은 남자 77.7세, 여자 84.5세로 과거에 비하여 빠르게 증가하고 있지만 ${ }^{[4]}$, 생활방식의 서구화로 인하여 심혈관질환의 발생 빈도 및 사망률 또한 과거에 비하여 급속도록 증가하고 있는 추세여 서 지속적으로 사회적 이슈로 대두되고, 그 치료뿐만 아니라 예방에도 관심을 가지게 되었다. 이러한 심혈 관질환 사망의 주요 요인으로는 과거로부터 고혈압, 고지혈증, 흡연 등의 건강위험 요소와[5], 비만관련 인 자 ${ }^{[6]}$, 낮은 신체활동, 심폐체력 부족 ${ }^{[7]}$, 대사증후군 ${ }^{[8]}$ 등을 주목해 오고 있고, 여기에 더해 염증반응 지표 ${ }^{[9],[10]}$ 와 산화적 스트레스 ${ }^{[11]}$ 도 심혈관질환 발생에 중요 한 원인으로 보고되고 있다. NCEP(National Cholesterol Education Program)는 심혈관질환 연구에서 처음으로 각자 가지고 있는 위험인자를 분류하여 그에 따른 위 험도를 제시하였는데, 최근 발표된 NCEP-APT III

(National Cholesterol Education Program - Adult Treatment Panel III)에서는 심혈관질환과 관련된 독립 적인 위험인자로 높은 저밀도지단백 콜레스테롤 외에 5 가지(연령, 고혈압, 흡연, 심혈관질환의 가족력, 낮은 고밀도지단백 콜레스테롤)를 추가로 선정하고, 각 개 인이 가지고 있는 위험인자에 따라 앞으로 발생할 심 혈관질환 위험도를 제시하여 개별화된 치료에 이용 할 수 있도록 하였다 ${ }^{[12]}$. 또한 제시한 독립적인 위험인 자들은 일반사람들에게 흔히 발견되며 이들 요소를 조절하였을 때 질환을 적극적으로 예방할 수 있다고 설명하였다. 이처럼 심혈관질환은 여러 위험요인들의 복잡한 상호작용에 의한 다인성 질환(multi factorial disease)으로서 단일 위험요인으로 심혈관질환을 추정 하는 것보다 주요 위험요인을 함께 고려하는 것이 효
과적인 예방에 도움이 된다 ${ }^{[13]}$.

이렇게 심혈관질환의 여러 관련인자 연구를 비롯하 여 직업 관련성도 연구되고 있지만 ${ }^{[14]}$, 경찰관에 대한 연구는 많이 부족하여 최근 전우진 등(2013) ${ }^{[15]}$ 의 연구 를 제외하면, 대부분의 경찰관 관련연구는 직무스트레 스 및 외상후 스트레스 장애에 맞춰져 있다[16],[17].

따라서 본 연구는 경찰관의 심혈관질환 유병율과 관련인자를 연구하여 경찰관의 효율적인 인력관리와 향후 비교 연구 등을 위한 기초자료를 제공하고자 한 다.

\section{II. 대상 및 방법}

\section{1. 대상 및 검사방법}

본 연구는 2010년 7월 29일부터 2010년 10월 7일까 지 ${ }^{201} \mathrm{Tl}-\mathrm{SPECT}$ 를 통해 심혈관 검사를 시행한 경찰공 무원 500 명의 데이터를 활용하여 경찰관의 심혈관질 환에 영향을 미치는 요인과 그로 인한 관련성을 분석 하였다. ${ }^{201} \mathrm{Tl}$-SPECT 검사는 $111 \sim 148 \mathrm{MBq}(3 \sim 4 \mathrm{mCi})$ 의 ${ }^{201} \mathrm{Tl}$ 을 주사하고 10 분 후 Stress 영상, 3 시간 후 Rest 영상을 촬영하였으며, 사용 장비는 저에너지콜리메이 터(Low Energy High Resolution, LEHR)를 장착한 INPINIA(GE, Tirat Hacarmel, Israel) 장비를 사용하였 고, 영상은 1.3배로 확대하여 우에서 좌로 Total Angular Range $180^{\circ}$, View angle은 $6^{\circ}$ 간격으로 멈춤 당 60 초씩 총 30 개의 투사영상을 Matrix는 64 x 64로 촬영 을 하였다. 평균 심박주기를 기준으로 $35 \%$ 창을 열어 한 주기 당 8 Frame을 얻었다. 게이트 201Tl-SPECT 검 사 후 QGS 소프트웨어를 이용하여 구혈율을 계산하 였고, 영상의 재구성은 Butterworth를 시행하였으며, 심 장 축을 정하고 단축, 수직장축, 수평장축 상을 만들었 다.

\section{2. 조사 내용}

경찰관들의 개인별 특성으로는 나이, 성별, 심혈관 질환 가족력을 조사하였고, 직무관련 특성으로 계급, 근무지역, 근무연수를 조사하였다. 생활 특성 및 과거 병력으로는 흡연 유무, 고혈압, 당뇨, 고지혈증을 조사 
하였고, 진단검사 의학적으로는 콜레스테롤, 중성지방, 고밀도지단백콜레스테롤(HDL), 저밀도지단백콜레스테 롤(LDL), Homocysteine, 혈액응고인자(PT, PPTa)를 조 사 하였다.

\section{3. 분석 방법}

자료처리는 SPSS Win. 18.0을 사용하였고 구체적인 통계 방법은 다음과 같다.

첫째, 연구대상자의 일반적 특성별로 기초분석을 위하여 기술통계를 하였다.

둘째, 연구대상자의 일반적 특성별로 빈도분석을 통해 빈도와 백분율을 구하였다.

셋째, 연구대상자의 심혈관질환 현황을 알아보기 위해 빈도분석을 통해 빈도와 백분율을 구하였다.

넷째, 연구대상자의 특성 및 요인에 따른 심혈관질 환 관련성을 검정을 위해 Pearson's chi-square test를 실 시하였고, 명목변수 및 최소 기대 빈도에 따라 Fisher's Exact test를 실시하였다.

다섯째, 교차분석을 토대로 다중 로지스틱 회귀분 석(Multiple Logistic Regression Analysis)을 이용하여 경 찰관 심혈관질환에 영향을 미치는 요인과 요인들의 교차비 및 $95 \%$ 신뢰구간을 산출하였다.

\section{III. 결 과}

\section{1. 연구 대상자의 일반적 특성}

\section{1. 개인 특성}

연구 대상자는 남자가 $99.0 \%$ 였으며, 평균 연령은 $48.80 \pm 6.45$ 세, 연령별 분포는 50 세 초과가 $43.8 \%$ 로 가 장 많고 그 뒤로 46 50세, 41 45세의 순서였다[Table 1].
Table 1. Individual characteristics

\begin{tabular}{ccc}
\hline Variables & Classification & Frequency (\%) \\
\hline \multirow{2}{*}{ 성별 } & 남자 & $495(99.0)$ \\
& 여자 & $5(1.0)$ \\
\hline \multirow{3}{*}{ 나이 } & $30 \sim 35$ 세 & $8(1.6)$ \\
& $36 \sim 40$ 세 & $56(11.2)$ \\
& $41 \sim 45$ 세 & $103(20.6)$ \\
& $46 \sim 50$ 세 & $114(22.8)$ \\
& $>50$ 세 & $219(43.8)$ \\
\hline
\end{tabular}

\section{2. 직무 특성}

연구 대상자의 직급별 분포는 경위가 $50.8 \%$ 로 가장 많았고, 근무지역은 서울이 $24.8 \%$ 로 가장 많았다. 재직 기간별로는 21 30년이 $47.8 \%, 11 ~ 20$ 년이 $39.8 \%$ 등의 순으로 나타났다[Table 2].

Table 2. Work characteristics

\begin{tabular}{ccc}
\hline Variables & classification & Frequency (\%) \\
\hline \multirow{3}{*}{ 계급 } & $\leq$ 경장 & $37(7.4)$ \\
& 경사 & $157(31.4)$ \\
& 경위 & $254(50.8)$ \\
& $\geq$ 경감 & $52(10.4)$ \\
\hline 서울 & $124(24.8)$ \\
& 경기도 & $92(18.4)$ \\
근무지역 & 강원도 & $42(8.4)$ \\
& 충청도 & $73(14.6)$ \\
& 경상도 & $80(16.0)$ \\
& 전라도-제주 & $89(17.8)$ \\
\hline & $1 \sim 10$ & $22(4.4)$ \\
재직기간 & $11 \sim 20$ & $199(39.8)$ \\
(year ) & $21 \sim 30$ & $239(47.8)$ \\
& $\geq 31$ & $40(8.0)$ \\
\hline
\end{tabular}

\section{3. 생활 특성}

연구대상자의 생활 특성은 비흡연자가 $58.8 \%$, 고혈 압이 있는 사람이 $52.2 \%$, 당뇨가 없는 사람이 $86.2 \%$, 고지혈증이 없는 사람이 $64.6 \%$, 심혈관 가족력이 없는 사람이 $77.6 \%$ 로 다빈도를 나타났다[Table 3]. 
"Factor Analysis of Effect on Cardiovascular Disease of Korean Police Officers"

Table 3. Life characteristics

\begin{tabular}{ccc}
\hline Variables & Classification & Frequency(\%) \\
\hline \multirow{2}{*}{ 흡연 } & 비흡연 & $294(58.8)$ \\
& 흡연 & $206(41.2)$ \\
\hline \multirow{2}{*}{ 고혈압 } & 없음 & $239(47.8)$ \\
& 있음 & $261(52.2)$ \\
\hline \multirow{2}{*}{ 당뇨 } & 없음 & $431(86.2)$ \\
& 있음 & $69(13.8)$ \\
\hline \multirow{2}{*}{ 고지혈증 } & 없음 & $323(64.6)$ \\
& 있음 & $177(35.4)$ \\
\hline \multirow{2}{*}{ 심혈관가족력 } & 없음 & $388(77.6)$ \\
& 있음 & $112(22.4)$ \\
\hline
\end{tabular}

\section{4. 진단검사 의학적 특성}

연구대상자의 진단검사 의학적 특성은 콜레스테롤 수치에 이상이 있는 사람이 $15.8 \%(\mathrm{High}+\mathrm{Low})$, 중성지 방 수치에 이상이 있는 사람이 $40.8 \%(\mathrm{High})$, 고밀도지 단백에 이상이 있는 사람이 $46.2 \%(\mathrm{High}+\mathrm{Low})$, 저밀도 지단백에 이상이 있는 사람이 $16 \%($ High), Homocystein 이 비정상인 사람이 $3.6 \%$ (High+Low), 혈액응고인자 PT에 이상이 있는 사람이 $1 \%(\mathrm{High}+\mathrm{Low})$, 혈액응고인 자 $\mathrm{aPPT}$ 에 이상이 있는 사람은 $62.4 \%$ (High+Low)로 나 타났다[Table 4].

Table 4. Laboratory medicine characteristics

\begin{tabular}{ccc}
\hline \multirow{2}{*}{ Variables } & Classification & Frequency(\%) \\
\hline \multirow{2}{*}{ 콜레스테롤 } & Normal & $421(84.2)$ \\
& High & $60(12.0)$ \\
& Low & $19(3.8)$ \\
\hline \multirow{2}{*}{ 중성지방 } & Normal & $296(59.2)$ \\
& High & $204(40.8)$ \\
\hline \multirow{3}{*}{ 고밀도지단백 } & Normal & $269(53.8)$ \\
& High & $7(1.4)$ \\
\hline \multirow{2}{*}{ 저밀도지단백 } & Low & $224(44.8)$ \\
\hline \multirow{3}{*}{ Homocystein } & Normal & $420(84.0)$ \\
& High & $80(16.0)$ \\
\hline \multirow{2}{*}{ PT } & Normal & $482(96.4)$ \\
& High & $17(3.4)$ \\
& Low & $1(0.2)$ \\
\hline \multirow{2}{*}{ aPPT } & Normal & $495(99.0)$ \\
& High & $2(0.4)$ \\
& Low & $3(0.6)$ \\
\hline
\end{tabular}

\section{2. 심혈관질환 현황 특성}

연구 대상자의 ${ }^{201} \mathrm{Tl}-\mathrm{SPECT}$ 검사에서는 이상이 있는 사람이 $52 \%$ 였으며, $\mathrm{LVEF}($ Left Ventricular Ejection Fraction)값에 이상이 있게 나타난 사람이 $5.2 \%$ 였다. ${ }^{201} \mathrm{Tl}-\mathrm{SPECT}$ 검사에서 이상이 있게 나타난 사람의 혈 관 부위는 RCA $18.6 \%$, LAD RCA $10.2 \%, \mathrm{LAD} 9.8 \%$ 의 순으로 나타났다[Table 5].

Table 5. Method characteristics

\begin{tabular}{|c|c|c|}
\hline Variables & classification & Frequency $(\%)$ \\
\hline \multirow{2}{*}{${ }^{201} \mathrm{TI}$-SPECT } & 없음 & $240(48.0)$ \\
\hline & 있음 & $260(52.0)$ \\
\hline \multirow{2}{*}{ LVEF } & 정상 & $474(94.8)$ \\
\hline & 이상 & $26(5.2)$ \\
\hline \multirow{9}{*}{ 혈관부위 } & 정상 & $240(48.0)$ \\
\hline & $\angle A D *$ & $49(9.8)$ \\
\hline & LCX** & $13(2.6)$ \\
\hline & $R C A \star \star \star$ & $93(18.6)$ \\
\hline & $\angle A D$ & $17(3.4)$ \\
\hline & LAD RCA & $51(10.2)$ \\
\hline & LCX RCA & $24(4.8)$ \\
\hline & LAD LCX RCA & $13(2.6)$ \\
\hline & $\begin{aligned} * \mathrm{LAD}: & \text { Left } a \\
& \star \star \mathrm{LCX} \\
& \star \star \star \mathrm{RCA}\end{aligned}$ & $\begin{array}{l}\text { descending ar } \\
\text { circumflex an } \\
\text { t coronary ar }\end{array}$ \\
\hline
\end{tabular}

\section{3. 관련성 검정}

\section{1. 심혈관질환 일반적 특성 관련성 검정}

일반적 특성중 연령대(나이)는 연구 대상자의 심혈 관질환과 관련이 있는 것으로 나타났으며 $(\mathrm{p}<0.05)$, 성 별은 관련이 없었다 $(\mathrm{P} \geq 0.05)[$ Table 6].

Table 6. Relevant of general characteristics of cardiovascular disease

\begin{tabular}{|c|c|c|c|c|c|}
\hline \multirow{2}{*}{$\begin{array}{c}\text { Varia- } \\
\text { bles }\end{array}$} & \multirow{2}{*}{$\begin{array}{c}\text { Classif- } \\
\text { ication }\end{array}$} & \multicolumn{2}{|c|}{ Frequency (\%) } & \multirow{2}{*}{$x^{2}$} & \multirow{2}{*}{$P$} \\
\hline & & No & Yes & & \\
\hline \multirow{2}{*}{ 성별 } & 남 & $236(47.3)$ & $259(52.7)$ & \multirow{2}{*}{2.07} & \multirow{2}{*}{0.20} \\
\hline & 여 & $4(80.0)$ & $1(20.0)$ & & \\
\hline \multirow{5}{*}{$\begin{array}{c}\text { 나이 } \\
\text { (year) }\end{array}$} & 30 35 & $1(12.5)$ & $7(87.5)$ & \multirow{5}{*}{14.23} & \multirow{5}{*}{0.01} \\
\hline & $36 \sim 40$ & $28(50.0)$ & $28(50.0)$ & & \\
\hline & $41 \sim 45$ & $52(50.5)$ & $51(49.5)$ & & \\
\hline & $46 \sim 50$ & $68(59.6)$ & $46(40.4)$ & & \\
\hline & $\geq 50$ & $91(41.6)$ & $128(58.4)$ & & \\
\hline
\end{tabular}




\section{2. 심혈관질환 직무 특성 관련성 검정}

연구대상자의 심혈관질환은 계급, 지역, 근무연수 등과 관련이 없었다( $\mathrm{p}>0.05)[$ Table 7].

Table 7. Relevant of work characteristics of cardiovascular

\begin{tabular}{|c|c|c|c|c|c|}
\hline \multirow{2}{*}{$\begin{array}{c}\text { Var iab- } \\
\text { les }\end{array}$} & \multirow{2}{*}{$\begin{array}{c}\text { Classif- } \\
\text { ication }\end{array}$} & \multicolumn{2}{|c|}{ Frequency (\%) } & \multirow{2}{*}{$x^{2}$} & \multirow{2}{*}{$P$} \\
\hline & & No & Yes & & \\
\hline \multirow{4}{*}{ 계급 } & $\leq$ 경장 & $17(45.9)$ & $20(54.1)$ & \multirow{4}{*}{5.18} & \multirow{4}{*}{0.16} \\
\hline & 경사 & $87(55.4)$ & $70(44.6)$ & & \\
\hline & 경위 & $114(44.9)$ & $140(55.1)$ & & \\
\hline & $\geq$ 경감 & $22(42.3)$ & $30(57.7)$ & & \\
\hline \multirow{6}{*}{$\begin{array}{l}\text { 근무 } \\
\text { 지역 }\end{array}$} & 경기도 & $51(55.4)$ & $41(44.6)$ & \multirow{6}{*}{9.02} & \multirow{6}{*}{0.11} \\
\hline & 강원도 & $25(59.5)$ & $17(40.5)$ & & \\
\hline & 서울시 & $56(45.2)$ & $68(54.8)$ & & \\
\hline & 전라도 & $40(44.9)$ & $49(55.1)$ & & \\
\hline & 경상도 & $30(37.5)$ & $50(62.5)$ & & \\
\hline & 충청도 & $38(52.1)$ & $35(47.9)$ & & \\
\hline \multirow{4}{*}{$\begin{array}{c}\text { 근무 } \\
\text { 연수 } \\
\text { (year) }\end{array}$} & $1 \sim 10$ & $9(40.9)$ & $13(59.1)$ & \multirow{4}{*}{6.63} & \multirow{4}{*}{0.09} \\
\hline & $11 \sim 20$ & 106(53.3) & $93(46.7)$ & & \\
\hline & $21 \sim 30$ & $112(46.9)$ & $127(53.1)$ & & \\
\hline & $\geq 30$ & $13(32.5)$ & $27(67.5)$ & & \\
\hline
\end{tabular}

\section{3. 심혈관질환 생활 특성 및 과거병력 관련성 검정}

생활 특성 및 과거병력 중 흡연, 고혈압, 고지혈증 은 심혈관질환과 관련이 있었으며 $(\mathrm{p}<0.05)$, 당뇨와 심 혈관 가족력은 관련이 없는 것으로 나타났다 $(\mathrm{P} \geq$ 0.05)[Table 8].

Table 8. Relevant of life characteristics of cardiovascular disease

\begin{tabular}{|c|c|c|c|c|c|}
\hline \multirow{2}{*}{$\begin{array}{c}\text { Var iabl- } \\
\text { es }\end{array}$} & \multirow{2}{*}{$\begin{array}{l}\text { Classif- } \\
\text { ication }\end{array}$} & \multicolumn{2}{|c|}{ Frequency (\%) } & \multirow{2}{*}{$x^{2}$} & \multirow{2}{*}{$P$} \\
\hline & & No & Yes & & \\
\hline 흡연 & $\begin{array}{c}\text { 비흡연 } \\
\text { 흡연 }\end{array}$ & $\begin{array}{l}156(53.1) \\
84(40.8)\end{array}$ & $\begin{array}{l}138(46.9) \\
122(59.2)\end{array}$ & 7.32 & 0.01 \\
\hline 고혈압 & $\begin{array}{l}\text { 정상 } \\
\text { 비정상 }\end{array}$ & $\begin{array}{l}131(54.8) \\
109(41.8)\end{array}$ & $\begin{array}{l}108(45.2) \\
152(58.2)\end{array}$ & 8.51 & 0.00 \\
\hline 당뇨 & $\begin{array}{l}\text { 없음 } \\
\text { 있음 }\end{array}$ & $\begin{array}{c}211(49.0) \\
29(42.0)\end{array}$ & $\begin{array}{c}220(51.0) \\
40(58.0)\end{array}$ & 1.14 & 0.29 \\
\hline 고지혈증 & $\begin{array}{l}\text { 없음 } \\
\text { 있음 }\end{array}$ & $\begin{array}{l}169(52.3) \\
71(40.1)\end{array}$ & $\begin{array}{l}154(47.7) \\
106(59.9)\end{array}$ & 6.83 & 0.01 \\
\hline $\begin{array}{l}\text { 심혈관 } \\
\text { 가족력 }\end{array}$ & $\begin{array}{l}\text { 없음 } \\
\text { 있음 }\end{array}$ & $\begin{array}{l}192(49.5) \\
48(42.9)\end{array}$ & $\begin{array}{l}196(50.5) \\
64(57.1)\end{array}$ & 1.53 & 0.22 \\
\hline
\end{tabular}

\section{4. 심혈관질환 진단검사 의학적 특성 관련성 검정}

진단검사 의학적 특성에서는 고밀도지단백에 따른 심혈관 관련 분석에서 관련이 있는 것으로 나타났고 $(\mathrm{p}<0.05)$, 콜레스테롤, 중성지방, 저밀도지단백, Homocy stein, 혈액응고인자(PT, aPTT)에서는 관련이 없는 것으 로 나타났다 $(\mathrm{P} \geq 0.05)$ [Table 9].

Table 9. Relevant of laboratory medicine characteristics of cardiovascular disease

\begin{tabular}{|c|c|c|c|c|c|}
\hline \multirow{2}{*}{$\begin{array}{c}\text { Var iabl- } \\
\text { es }\end{array}$} & \multirow{2}{*}{$\begin{array}{l}\text { Classif- } \\
\text { ication }\end{array}$} & \multicolumn{2}{|c|}{ Frequency $(\%)$} & \multirow{2}{*}{$x^{2}$} & \multirow{2}{*}{$P$} \\
\hline & & No & Yes & & \\
\hline 콜레 & 정상 & $204(48.5)$ & $217(51.5)$ & \multirow{2}{*}{0.72} & \multirow{2}{*}{0.70} \\
\hline 스테롤 & 비정상 & $36(45.6)$ & $43(54.4)$ & & \\
\hline \multirow{2}{*}{ 중성지방 } & 정상 & $148(50.0)$ & $148(50.0)$ & \multirow{2}{*}{1.16} & \multirow{2}{*}{0.28} \\
\hline & 비정상 & $92(45.1)$ & $112(54.9)$ & & \\
\hline 고밀도 & 정상 & $147(54.6)$ & $122(45.4)$ & \multirow{2}{*}{10.33} & \multirow{2}{*}{0.01} \\
\hline 지단백 & 비정상 & $93(40.2)$ & $138(59.8)$ & & \\
\hline 저밀도 & 정상 & $206(49.0)$ & $214(51.0)$ & \multirow{2}{*}{1.15} & \multirow{2}{*}{0.28} \\
\hline 지단백 & 비정상 & $34(42.5)$ & $46(57.5)$ & & \\
\hline \multirow{2}{*}{ PT } & 정상 & $238(48.1)$ & $257(51.9)$ & \multirow{2}{*}{0.26} & \multirow{2}{*}{0.88} \\
\hline & 비정상 & $2(40.0)$ & $3(60.0)$ & & \\
\hline \multirow{2}{*}{ aPPT } & 정상 & $94(50.0)$ & $94(50.0)$ & \multirow{2}{*}{1.62} & \multirow{2}{*}{0.45} \\
\hline & 비정상 & $146(46.9)$ & 166(53.1) & & \\
\hline
\end{tabular}

\section{5. 심혈관질환 $\mathrm{LVEF}$ 관련성 검정}

연구 대상자의 $\mathrm{LVEF}$ 수치는 심혈관질환과 관련이 있었다 $(\mathrm{p}<0.05)$ [Table 10].

Table 10. Relevant of LVEF of cardiovascular disease

\begin{tabular}{cccccc}
\hline \multirow{2}{*}{$\begin{array}{c}\text { Variab- } \\
\text { les }\end{array}$} & $\begin{array}{c}\text { Classif- } \\
\text { ication }\end{array}$ & \multicolumn{2}{c}{ Frequency $(\%)$} & \multirow{2}{*}{$\chi^{2}$} & $P$ \\
\cline { 3 - 4 } LVEF & 정상 & $235(49.6)$ & 239(50.4) & & \\
비정상 & $5(19.2)$ & $21(80.8)$ & 9.09 & 0.00 \\
\hline
\end{tabular}

\section{4. 요인별 심혈관질환 다중 로지스틱 회귀 분석}

요인별 심혈관질환 다중 로지스틱 회귀 분석 결과, 연령별로 35세 이하는 46 50세의 경우 비교위험도가 0.1 배로 나타났으며, 흡연을 하는 사람은 비흡연자의 
보다 1.80 배, 고혈압 있는 사람은 고혈압이 없는 사람 보다 1.63배, 고지혈증이 있는 사람은 없는 사람보다 1.48 배, $\mathrm{HDL}$ 이 낮은 사람은 정상인 사람보다 1.82 배, $\mathrm{LVEF}$ 가 비정상인 사람은 정상인 사람보다 4.38 배 심 혈관질환이 높게 나타났다 $(\mathrm{p}<0.05)[$ Table 11].

Table 11. Multiple logistic regression analysis by factor

\begin{tabular}{|c|c|c|c|c|c|c|}
\hline \multirow[t]{2}{*}{ Variables } & \multirow[t]{2}{*}{ B } & \multirow[t]{2}{*}{$\mathrm{F}$} & \multirow[t]{2}{*}{$P$} & \multirow[t]{2}{*}{ OR } & \multicolumn{2}{|c|}{$\begin{array}{c}\text { EXP(B)에 대한 } \\
95 \% \text { 신뢰구간 }\end{array}$} \\
\hline & & & & & 하한 & 상한 \\
\hline Age(30 35) & & 4 & .02 & & & \\
\hline Age (36 40) & -1.770 & 1 & .11 & 0.17 & 0.02 & 1.52 \\
\hline Age(41 45) & -1.951 & 1 & .08 & 0.14 & 0.02 & 1.23 \\
\hline Age(46 50) & -2.331 & 1 & .03 & 0.10 & 0.01 & 0.84 \\
\hline $\operatorname{Age}(\geq 51)$ & -1.619 & 1 & .14 & 0.20 & 0.02 & 1.69 \\
\hline 흡연 & 0.587 & 1 & .00 & 1.80 & 1.23 & 2.64 \\
\hline 고혈압 & 0.491 & 1 & .01 & 1.63 & 1.12 & 2.38 \\
\hline 고지혈증 & 0.393 & 1 & .05 & 1.48 & 1.00 & 2.20 \\
\hline HDL & & 2 & .01 & & & \\
\hline HOL (High) & 0.729 & 1 & .36 & 2.07 & 0.43 & 10.00 \\
\hline HDL (Low) & 0.600 & 1 & .00 & 1.82 & 1.25 & 2.66 \\
\hline LVEF & 1.478 & 1 & .01 & 4.38 & 1.54 & 12.45 \\
\hline
\end{tabular}

\section{$\mathrm{N}$. 고찰 및 결론}

심혈관질환의 예방법은 질환발생 자체를 억제하는 1 차 예방법과 질환진행을 억제하는 2 차 예방법으로 나 누어지는데, 1 차 예방은 다시 조절 가능인자와 조절 할 수 없는 인자로 구별할 수 있고, 조절 가능 인자는 생활습관 관련 인자와 생리적인 위험인자로 나눌 수 있다 ${ }^{[18]}$. 조절할 수 없는 일반적 특성 요인으로는 나이, 성별 등이 있으며 조절 가능한 생활 습관 요인으로는 고혈압, 당뇨, 고지혈증, 흡연, 조절 가능한 생리적인 요인으로 총콜레스테롤, 중성지방, 고밀도지단백콜레 스테롤 $(\mathrm{HDL})$, 저밀도지단백콜레스테롤 $(\mathrm{LDL})$, 염증수 치(PT, aPPT) 등으로 구분 할 수 있다. 본 연구에서는 특정 집단인 경찰관을 대상으로 기존의 심혈관질환 위험인자와 심혈관질환 사이의 관련성을 확인하고 특 별히 차별화를 보이는 경찰관만의 심혈관질환 관련 요인 특징이 나타나는지 여부 등을 확인하고 향후 경 찰관 인력관리를 위한 기초자료를 제공하고자 하였다. 이를 위하여 국립경찰병원에서 2010년 3월에서 2010년
10 월까지 심혈관질환 특화검사를 실시한 경찰관을 대 상으로 관련 값을 정량분석을 하였는데, ${ }^{201} \mathrm{Tl}-\mathrm{SPECT}$ 검사를 시행한 총 562 명중 심혈관질환 관련 조사 변수 에 대한 데이터 누락이 없는 500 명의 자료를 활용하여 심혈관질환 여부와 요인과의 관련성을 연구하였다.

연구결과 경찰관의 심혈관질환과 관련성 있게 나온 요인은 연령대, 흡연, 고혈압, 고지혈증, 고밀도지단백 (HDL), LVEF 였다 $(\mathrm{p}<0.05)$.

개인의 일반적 특성에서 관련있었던 연령과 심혈관 질환과의 관계는 이미 관련성이 검증되고 지속적으로 연구되고 있는 사항이다 ${ }^{[19]}$. 다만, 본 연구의 회귀분석 에서 연령증가에 따른 음의 관계를 나타낸 것은 본 연 구의 대상자의 평균 연령이 $48.80 \pm 6.45$ 세로 높고 저 연령층의 대상자가 상대적으로 적기 때문인 것으로 보인다.

생활특성 및 과거병력과 관련하여, 심혈관질환과 관련한 흡연 요인의 회귀분석 결과 흡연을 하는 사람 은 흡연을 하지 않는 사람보다 1.80 배( $95 \%$ CI, 1.23-2.64)의 비교위험도를 나타냈는데, 이는 과거 Framingham 연구를 포함한 Pooling Project 연구 ${ }^{[20]}$ 에서 다른 위험 요인을 제외한 경우 흡연자가 비흡연자의 비해 심장질환의 위험률이 2 3배 정도 높았다는결과 와 부합된다. 또한 국내 이은하 등(2010) ${ }^{[21]}$ 의 한국인의 흡연과 사망에 관한 코호트 연구에 따르면 흡연을 하 지 않는 사람과 흡연을 하는 사람의 비교 위험도는 1.2 배(95\% CI, 0.8-2.0)였으며, 흡연기간이 길수록 위험도 가 커져 본 연구 결과를 뒷받침하고 있다. 한편, 혈압 은 관리를 통해서 합병증을 예방할 수 있는 부분으로 대부분의 나라에서 고혈압을 조기에 발견하고 치료하 도록 권장하고 있는데 ${ }^{[22]}$, 연구에 따르면 우리나라의 경우 고혈압이 심혈관질환 발생에 기여하는 정도는 $21 \%$ 라고 알려져 있고 ${ }^{[23]}$, 고혈압 유병자의 경우 평균 이완기 혈압 $2 \mathrm{mmHg}$ 낮추면 심혈관 질환 발생위험이 $6 \%$ 줄어든다고 보고되고 있다 ${ }^{[24]}$. 본 연구에서의 회귀 분석 결과 심혈관질환에 대한 고혈압 요인의 비교위 험도는 $1.63(95 \% \mathrm{CI}, 1.12-2.38)$ 이었다. 또한 고지혈증은 있는 사람의 없는 사람대비 비교 위험도가 1.48 배( $95 \%$ CI, 1.00 2.20)의 결과를 보였는데, 고지혈증은 심혈관 질환의 관련인자로 유형에 따른 치료법이 제시되는 등 많은 연구가 이루어지고 있는 부분으로 ${ }^{[25]}$ 관련성 
이 입증되어 있다.

진단검사 의학적 특성에서 고밀도지단백콜레스테롤 (HDL)과 심혈관질환은 관련성이 있었고, 선행연구들 에 따르면 $\mathrm{HDL}$ 은 심장질환의 보호인자로써리 콜레스 테롤 수치와는 반대로 $1 \mathrm{mg} / \mathrm{dl}$ 이 높을 때 마다 2 3\% 씩 심혈관질환을 줄일 수 있는 것으로 알려져 있달]. 본 연구 회귀분석에서 $\mathrm{HDL}$ 이 낮은 사람은 정상인 사 람보다 1.82배(CI : 1.25-2.66)의 비교위험도를 보였는데, 일부 연구 따르면 중성지방의 농도 증가에 따라 $\mathrm{HDL}$ 의 수치가 높은 사람에서도 심혈관질환의 위험도가 증가한다는 연구도 ${ }^{[27]}$ 있어 본 연구결과에서 중성지방 농도와의 관련성을 고려해볼 수 있으나 본 연구에서 는 중성지방에 대한 정확한 농도치를 확인할 수 없고 대상자를 정상과 비정상의 범주로 구분하여 향후 지 속적 연구가 필요한 부분으로 사료된다.

마지막으로 $\mathrm{LVEF}(\%)$ 수치는, ${ }^{201} \mathrm{Tl}-\mathrm{SPECT}$ 검사에서 좌심실의 수축.이완을 나타내는 것으로 좌심실비대는 혈압요소에 영향을 주고 관상동맥질환 등 심혈관질환 에 영향을 준다 ${ }^{[28]}$. 본 연구에서도 고혈압과 LVEF 수 치가 심혈관질환과 관련성을 나타내고 있어 이런 기 존 연구와 같은 결과를 나타내고 있다.

본 연구에서의 제한점으로 연구의 대상자들의 경찰 관이라는 특성상 남성이 대부분을 차지하여 남여 성 별에 따른 비교가 용이치 못했고, 검사 대상자가 관련 질환이 있는 환자 대상이 아닌 검진을 위한 목적으로 진료를 실시한 사람이 대부분이어서 상대적으로 심각 한 수준의 심혈관질환은 찾기 힘들었고, 질환자로 분 류된 대부분이 중등정도(mild)의 질환자들로 질병단계 의 세밀 분류에 한계가 있었다. 그럼에도 불구하고 본 연구는 경찰관을 대상으로 한 질환 연구로써 경찰관 이라는 특정집단에 대한 심혈관질환에 대한 인과적 관련성을 살펴보았다는데 의의가 있다.

결과적으로 ${ }^{201} \mathrm{Tl}-\mathrm{SPECT}$ 검사를 통하여 알아 본 경 찰관의 심혈관질환에 영향을 미치는 요인은 기존 연 구를 통해 밝혀진 심혈관질환 영향 요인과 큰 차이를 나타내지 않았고, 직무 관련성에 대해선 통계적 유의 성을 찾을 수 없었다. 다만, 유의수준 0.1 의 영역에서 근무연수에 따른 관련성을 나타낸 부분에 대해 향후 지속적인 연구가 필요할 것으로 사료된다. 결론적으로
본 연구 자료는 경찰관의 심혈관질환의 예방과 관리 에 있어 경찰조직의 효율적인 인적관리와 경찰관을 위한 특화진료, 향후 비교 연구 등에 있어서의 기초자 료로 활용되길 기대한다.

\section{참고문헌}

[1] K.J. Peak, "Policing America: Pearson/Prentice Hall", 2006.

[2] http://www.ajunews.com/common/redirect.jsp?newsId=20110704000 462

[3] National Statistical Office, "2011 ANNUAL REPORT ON THE CAUSE OF DEATH STATISTICS", 2012.

[4] Korean Statistical Information Service, 2013 Website http://kosis.kr/nsportalStats/nsportalStats_0102Body.jsp?menuId=6\& $\mathrm{NUM}=156$

[5] Blair S.N., Kampert J.B., Kohl III H.W., Barlow C.E., Macera CA, Paffenbarger Jr R.S., et al. "Influences of cardiorespiratory fitness and other precursors on cardiovascular disease and all-cause mortality in men and women. JAMA", The journal of the American Medical Association, Vol. 276, No. 3, pp. 205-210, 1996.

[6] Després J.P., "The insulin resistance- dyslipidemic syndrome of visceral obesity: effect on patients' risk", Obesity research, Vol. 6, No. S1, pp. 8S-17S,1998.

[7] Cooper K.H., Gibbons L.W., "Physical fitness and all-cause mortality", Jama, Vol. 262, No. 10, pp. 2395-2401, 1989.

[8] Lakka T.A., Laaksonen D.E., Lakka H.M., Mannikko N., Niskanen L.K., Rauramaa R., et al., "Sedentary lifestyle, poor cardiorespiratory fitness, and the metabolic syndrome", Medicine and science in sports and exercise, Vol. 35, No. 8, pp. 1279-1286, 2003.

[9] Sloop G.D., Kevin J., Tabas I., Peter L., Martin R., "Atherosclerosis - an inflammatory disease", The New England journal of medicine. Vol. 340, No. 24, pp. 1928-1929, 1999.

[10] Kasapis C., Thompson P.D., "The Effects of Physical Activity on Serum C-Reactive Protein and Inflammatory MarkersA Systematic Review", Journal of the American College of Cardiology. Vol. 45, No. 10, pp. 1563-1569, 2005.

[11] Singh U., Jialal I., "Oxidative stress and atherosclerosis", Pathophysiology. Vol. 13,No. 3, pp. 129-142, 2006.

[12] Program T.R. to NCE., "Expert panel on detection, evaluation, and treatment of high blood cholesterol in adults (Adult treatment panel III) final report", Circulation. Vol. 106, pp. 3143-3421, 2002. 
[13] Korean Society of Lipidology and Atherosclerosis, "Lipidology and Atherosclerosis Guideline for Diagnosis and Treatment", 2009.

[14] J. Park, "Are Cerebrovascular and Cardiovascular Diseases among Employees Work-related?", Korean Journal of Occupational and Environmental Medicine, Vol. 17, No. 4, pp. 288-296, 2005.

[15] W.J. Jeon, J.H. Cho, "Factor Analysis on Cerebrovascular Disease of Korean Police Officers", Journal of the Korean Society of Radiology, Vol. 31, No. 7, pp. :293-299, 2013.

[16] Y.J. Son, Y.A. Song, E.Y. Choi, "The Relationship between Occupational Stress and Exhaustion in the Police", Journal of The Korean Society of Stress Medicine, Vol. 16, No. 3, pp. 225-231, 2008.

[17] D.K. Kwak, D.W. Kim, M.K. Kim, "A Study of PTSD from Police Job", Korea Association of Criminal psychology. Vol. 15, pp. 23-46, 2011.

[18] Swan H., Gersh B., Grayboys T., Ullyot D., "Evaluation and management of risk factors for the individual patient(case management)". J. Am. Coll. Cardiol., Vol. 27, pp. 1030-1047, 1996.

[19] Califf R., Armstrong P., Carver J., D'agostino R., Strauss W., "27th Bethesda Conference: matching the intensity of risk factor management with the hazard for coronary disease events", Task Force 5, Stratification of patients into high, medium and low risk subgroups for purposes of risk factor management, Journal of the American College of Cardiology, Vol. 27, No. 5, pp. 1007, 1996.

[20] Group P.P.R., "Relationship of blood pressure, serum choles-326 ANNALS NEW YORK ACADEMY OF SCIENCES terol, smoking habit, relative weight, and ECG abnormalities to incidence of major coronary events", Final report of the Pooling Project. J Chronic Dis., Vol. 31, pp. 201, 1978.

[21] E.H. Lee, S.K. Park, K.P. Ko, I.S. Cho, S.H. Chang, H.R. Shin, et al., "Cigarette Smoking and Mortality in the Korean Multi-center Cancer Cohort (KMCC) Study", J Prev Med Public Health, Vol. 43, No. 2, pp. 151-158, 2010.

[22] Jönsson B.G., "Cost-benefit of treating hypertension", Journal of hypertension Supplement: official journal of the International Society of Hypertension, Vol. 12, No. 10, pp. S65, 1994.

[23] S.H. Jee, I. Suh, I.S. Kim, L.J. Appel, "Smoking and atherosclerotic cardiovascular disease in men with low levels of serum cholesterol", JAMA: the journal of the American Medical Association, Vol. 282, No. 22, pp. 2149-2155, 1999.
[24] Cook N.R., Cohen J., Hebert P.R., Taylor J.O., Hennekens C.H., "Implications of small reductions in diastolic blood pressure for primary prevention", Archives of Internal Medicine. Vol. 155, No. 7, pp. 701, 1995.

[25] K.H. Han, "Control of Dyslipidemia", J Korean Med Assoc. Vol. 52, No. 3, pp. 299-311, 2009.

[26] Després J.P., Lemieux I., Dagenais G.R., Cantin B., Lamarche Bt., "HDL-cholesterol as a marker of coronary heart disease risk: the Quebec cardiovascular study", Atherosclerosis, Vol. 153, No. 2, pp. 263-272, 2000.

[27] ørgen Jeppesen J., Hein H.O., Suadicani P., Gyntelberg F., "Triglyceride concentration and ischemic heart disease an eight-year follow-up in the Copenhagen male study", Circulation, Vol. 97, No. 11, pp. 1029-1036, 1998.

[28] J.S. Park, C.G. Park, M.Y. Park, J.H. Park, Y.H. Kim, J.O. Na, et al., "Relation of Blood Pressure Components to Left Ventricular Hypertrophy and Coronary Heart Disease with Aging", Korean Circulation J., Vol. 34, No. 2, pp. 142-150, 2004. 